\title{
ГЕНДЕРНІ АСПЕКТИ ПРОФЕСІЙНОГО СПІЛКУВАННЯ ФАХІВЦІВ ІЗ СОЦІАЛЬНОЇ РОБОТИ
}

\author{
Перхайло Н. А. \\ кандидат педагогічних наук, доиент, \\ дочент кафедри сочіальної педагогіки і сочіальної роботи \\ Університет Григорія Сковороди в Переяславі \\ вул. Сухомлинського, 30, Переяслав, Київська область, Украӥна \\ orcid.org/0000-0002-3332-6256 \\ ne-la@ukr.net
}

\begin{abstract}
Ключові слова:
соиіальна робота, фахівець із сочіальної роботи, професійне спілкування, гендерні особливості професійного спілкування.
\end{abstract}

Автор статті порушує проблему оптимізації професійного спілкування фахівців із соціальної роботи шляхом формування комунікативної та гендерної культури. Із цією метою висвітлюються мотиви, завдання, зміст та особливості фахової комунікації в соціальній сфері. Наведена низка труднощів, які ускладнюють професійне спілкування соціальних працівників: широкий спектр завдань та повноважень; складні умови роботи; проблемний контингент; численні конфліктні ситуації; комунікативні маніпуляції; несприйняття суспільством тощо.

У статті визначено поняття гендеру в аспекті професійної діяльності та спілкування фахівців соціальних служб, у контексті партнерства суб' єктів соціальної сфери, зокрема чоловіків і жінок, - гендерного партнерства. Професійно-комунікативна культура фахівців із соціальної роботи тісно пов'язана з оволодінням гендерними особливостями спілкування. Серед останніх автор називає розбіжність у меті та мотивах спілкування чоловіків і жінок, відмінність комунікативних стратегій, стилів жіночого й чоловічого спілкування, змістове та мовленнєве наповнення висловлень представників різної статі. Водночас детально охарактеризовані особливості взаємодії у процесі професійного спілкування фахівців із соціальної роботи (встановлення й підтримання контактів, сприймання, зворотний зв'язок тощо).

Окрему увагу приділили гендерно маркованим конфронтаційній комунікації, стратегіям ведення дискусії, комунікативним перешкодам (когнітивні, емоційні і поведінкові розходження між статями), шляхам їх подолання та ін.

Опанування системи знань про гендерні перетворення у професійній діяльності, зокрема в соціальній сфері, формування в майбутніх фахівців iз соціальної роботи комплексу комунікативних умінь i навичок 3 урахуванням гендерних особливостей спілкування вимагає оновлення системи теоретичної і практичної підготовки студентів у вищій школі.

Важливим $є$ завдання підвищення професійної кваліфікації фахівцівпрактиків, фахової компетентності соціальних працівників шляхом збагачення сучасними інструментами професійної діяльності, зокрема засвоєння відомостей про гендерні особливості спілкування (клієнтів і колег), удосконалення навичок налагодження ефективної взаємодії з ними. 


\title{
GENDER ASPECTS OF SOCIAL WORK SPECIALISTS' PROFESSIONAL COMMUNICATION
}

\author{
Perkhailo N. A. \\ Candidate of Pedagogical Sciences, Associate Professor, \\ Associate Professor at the Department of Social Pedagogy and Social Work \\ Hryhoriy Skovoroda University in Pereyaslav \\ Suhomlyns'kogo str., 30, Pereyaslav, Kyiv region, Ukraine \\ orcid.org/0000-0002-3332-6256 \\ ne-la@ukr.net
}

Key words:

social work, social work specialist, professional communication, gender aspects of professional communication.
The author of the article raises the issue of optimizing the social work specialists' professional communication by forming communicative and gender culture. The motives, tasks, content and features of professional communication in the social sphere are highlighted for this purpose. A number of difficulties that complicate the social work specialists' professional communication: a wide range of tasks and powers; difficult working conditions; problem contingent; numerous conflict situations; communicative manipulations; public rejection, etc. are listed. The article defines the concept of gender in terms of professional activities and communication of social services professionals, in the context of partnership of social subjects, including men and women, that is gender partnership. The social work specialists' professional and communicative culture is closely related to mastering the gender features of communication. Among the latter, the author phrases the difference in the purpose and motives of communication between men and women; communication strategies difference, female and male communication styles; semantic and speech content of statements of different sex representatives. At the same time, the peculiarities of interaction in the process of social work specialists' professional communication are described in detail (establishing and maintaining contacts, perceptions, feedback, etc.). Particular attention is paid to gender-marked confrontational communication, conducting a discussion strategies, communication barriers (cognitive, emotional and behavioral differences between the sexes), ways to overcome them, etc. Mastering the system of knowledge about gender transformation in professional activities, in particular in the social sphere, the formation of future social workers a set of communicative skills and abilities taking into account gender specifics of communication requires updating the system of theoretical and practical training of students in higher education. It is important to improve the specialist-practitioners' professional skills, professional competence of social workers by enriching modern tools of professional activity, in particular, the mastering data about the gender characteristics of communication (clients and colleagues), improving the skills of establishing effective interaction with them.
Постановка проблеми. Інтеграція до європейського й світового простору вимагає врахування як високих сучасних стандартів професійної діяльності, так і запитів нинішнього суспільства на підготовленого, висококваліфікованого фахівця, здатного ефективно виконувати посадові обов'язки. Серед найактуальніших професійних характеристик фахівців із соціальної роботи вважаємо здатність до продуктивної комунікації, готовність налагоджувати результативну взаємодію з клієнтами, організовувати тісне партнерство 3 різними суб'єктами соціальної сфери.
Окремим питанням, що потребує особливої уваги, $\epsilon$ дослідження гендерних особливостей професійного спілкування в соціальній роботі - з'ясування основних їх проявів у діяльності працівників соціальних служб, різних категорій клієнтів, а також вироблення в майбутніх фахівців високого рівня гендерної культури, вмінь якісно організовувати комунікативну взаємодію.

Процес глобалізації вимагає дослідження гендерно маркованих ознак професійної взаємодії, зокрема в соціальній сфері, ролі гендерного концепту в продуктивному фаховому спілкуванні. 
Аналіз останніх досліджень i публікацій. Окремі питання регулювання гендерних відносин досліджували вітчизняні й зарубіжні вчені (Н. Болотіна, Е. Гансова, Т. Говорун, О. Горошко, Н. Грицяк, В. Довженко, В. Луговий, Т. Мельник, О. Мітіна, Н. Приходькіна та ін.), чиї роботи й стали теоретичною базою розвідки.

Метою цієї статті $\epsilon$ висвітлення гендерних особливостей професійного спілкування фахівців із соціальної роботи.

Виклад основного матеріалу. Феномен «гендер» здебільшого пов'язують 3 описом «соціальних, культурних і психологічних аспектів, співвідносних із рисами, нормами, стереотипами й ролями, характерними або бажаними для тих, кого суспільство вважає чоловіками чи жінками» [3]. Тобто говоримо про гендер як соціокультурну категорію, що охоплює суспільні норми, очікування, уявлення, пов'язані зі статтю. Як справедливо зауважує Л. Корнєва, «гендер - це безперервний процес продукування суспільством відмінностей у чоловічих і жіночих ролях, ментальних та емоційних характеристиках i, врешті-решт, у мовленнсвій поведінці» [7]. Гендерні відносини нині вивчаються не лише у зв'язку 3 необхідністю визначення взаємовідносин представників різних статей, їх місця й ролі в суспільстві, але й у світлі зростання активності жінки в різних сферах життєдіяльності, зокрема у соціальній роботі, яка небезпідставно давно вважається жіночою.

У процесі фахової комунікації важливо знати і враховувати гендерні ознаки професійного спілкування фахівців із соціальної роботи, особливості комунікативної поведінки працівників і клієнтів, а саме: емоційність, здатність підтримувати комунікативний контакт, співвідношення вербального й невербального спілкування, жестикуляція, міміка, темп мовлення тощо [10]. Зауважимо, що «змішування різних соціальних і комунікативних гендерних ролей вважають загрозою віковим суспільним настановам, чинниками руйнування жорсткої ієрархічної моделі або відхиленням від норми» $[8$, с. 68]. Налагодження ефективного професійного спілкування фахівців із соціальної роботи ми розглядаємо в контексті партнерства суб'єктів соціальної сфери, зокрема чоловіків і жінок, - гендерного партнерства, а також як запоруку ефективної взаємодії з клієнтами. Водночас це свідчить про гуманізацію суспільства, утвердження жіночого світогляду, емоційно насичених людських відносин, припинення зневаги до жінок, не лише визнання, а й захист прав людини, осмислення нових моделей взаємодії чоловіків і жінок [11].

Отже, гендер - це змодельована суспільством та підтримувана соціальними інституціями система цінностей, норм і характеристик поведінки чоловіків та жінок, стилю життя та способу мислення, ролей і відносин, набутих ними в процесі соціалізації, що насамперед визначається соціальними, політичними, економічними і культурними контекстами буття й фіксує уявлення про жінку і чоловіка залежно від їх статі [2; 4; 6; 7 тощо].

«Професійне спілкування фахівців із соціальної роботи розуміємо як процес взаємодії працівників із метою обміну професійно важливою інформацією, досвідом та ідеями, який організує спільну діяльність і спрямований на реалізацію поставленої професійної мети» [5, с. 42]. Характерні ознаки професійного спілкування в соціальній сфері зумовлені предметом (спільна справа й ставлення учасників до неї), потребою (службова необхідність у розв'язанні соціальних проблем), мотивами спілкування (інтереси справи; мовні дії, що регламентуються встановленими правилами поведінки і мають формально-рольовий, а не особистісний характер), метою (вирішення професійних та соціальних питань) тощо. Завданнями фахівців із соціальної роботи в процесі професійного спілкування є вислухати, «почути», зрозуміти і роз'яснити, довести, відповісти, переконати, створити позитивну емоційну атмосферу довіри чи ділового настрою, знайти підхід до клієнта [9]. Професійне спілкування фахівців із соціальної роботи пов'язане 3 низкою труднощів: надшироким спектром завдань та повноважень; складними умовами роботи (нічні рейди, взаємодія зі складними, алко- та наркозалежними й агресивними клієнтами, проблемним контингентом (занедбані, агресивні, із залежностями та ін.); численними конфліктними ситуаціями, непорозумінням, опором із боку клієнтів; комунікативними маніпуляціями; несприйняттям суспільством тощо.

Спілкування вимагає від фахівців із соціальної роботи як ініціаторів комунікативної взаємодії широкого арсеналу комунікативних знань про види, засоби, форми спілкування, високого рівня професійно-комунікативної компетентності, готовності шукати різні підходи в кожному конкретному випадку [9]. Окреме місце в цьому зв'язку належить гендерним особливостям (відмінностям) спілкування, що виявляються у процесі виконання певної соціальної та фахової ролі, підтримують чи активізують комунікативну діяльність мовця.

Як відомо, у процесі спілкування чоловіки й жінки мають різну мету: чоловіки, насамперед, прагнуть передати важливу інформацію, вирішити проблему, зберегти (підтримати) свободу та домінантний статус (часто маніпулюючи ним), самоствердитися, а жінки - розпочати, продовжити чи зміцнити фахові й емоційні контакти зі співрозмовниками [4; 6]. Різні цілі та мотиви комунікації, зумовлюють мовленнєві якості фахівців і формування різних стилів та стратегій їх спілкування [12]. 
Науковці (Ф. Бацевич, Л. Ботіна, Т. Говорун, Л. Корнєва, Л. Ставицька і т.д.) наполягають на існуванні чоловічого й жіночого стилів спілкування, зумовлених використанням відповідних комунікативних стратегій. Так, жіноча комунікація переважно орієнтована на позитивну атмосферу спілкування, рівноправні, добрі людські взаємини, партнерство, дистанційну близькість, альтруїзм (перевага чужих інтересів), очікування згоди, компромісу, приватність, використання натяків, а чоловіки скеровані на предмет мовлення, правильність рішення, факти (цифри, результати), соціальні статуси, владу (пріоритет), ієрархію соціальних ролей, самостійність, публічність, категоричність, наполегливість, активність, агресивність тощо.

Жіночі комунікативні стратегії гнучкіші, грунтуються на високій відповідальності, дисциплінованості та особистій зацікавленості, високій потребі в комунікації, меншій амбіційності, передбачуваності, експресивності, увазі до деталей, здатності продуктивно поєднувати кооперативні й індивідуалістичні стратегії соціального менеджменту, відкритості у спілкуванні як із жінками, так і з чоловіками, потребі в колегіальному обговоренні проблем, обережності та відтермінуванні прийняття рішення, готовності підкоритися авторитету, традиціям, недостатньому вмінні розділяти особисте й професійне та ін.

Натомість чоловічі комунікативні стратегії зазвичай передбачають домінування, конкуренцію, логічність, тематичну однолінійну, «психологічну глухоту» (абстрагування від несуттєвого, другорядного під час бесіди), увагу до змістового аспекту спілкування, зниження його емоційності (обмежене вираження болю, образи, захвату. Хоча частіше виказують гнів, роздратування, невдоволення, обурення), самодемонстрацію, підкреслення власної поінформованості, компетентності, готовність до командної роботи, небагатослівність, схильність до авторитарних, ризикованих рішень, які приймають легше і швидше, ніж жінки, частіше вживання лайливих слів, пріоритет роботи над приватним життям, здатність до пошуку нестандартних рішень, новаторських пропозицій та швидких асоціацій, прагнення диктувати тон та тему розмови тощо.

Зауважимо, що саме зі стилем спілкування пов'язують гендерні стереотипи, тобто усталені судження, мотиви й норми поведінки, які асоціюють із чоловіками чи жінками [6]. Для налагодження контакту 3 клієнтами фахівці із соціальної роботи мають враховувати гендерні особливості тематичних уподобань чоловіків і жінок. Так, чоловіки схильні обговорювати політику, економіку, техніку, технічний прогрес, зброю, спорт, музику, жінок, секс. Для жінок більше характерні розмови про сім'ю, дітей, побут, зовнішність, здоров'я, хобі та ін. [7, с. 108-109].
Результативність професійного спілкування значною мірою залежить від обізнаності із його гендерними особливостями. Чоловіче професійне спілкування монологічніше, містить безапеляційні судження, характеризується повторюваним використанням вставних слів (ствердні, констатувальні, логічного викладу) типу «звичайно», «безумовно», «по-перше», «по-друге», «отже», прямих недвозначних визначень («ніхто», «ніколи», «абсолютно»), мінімальним вираженням емоцій за допомогою одноманітних лексичних прийомів, частішим вживанням іменників і прикметників. Водночас голосовий діапазон чоловічого мовлення ширший, із більшою силою голосу та ригідністю голосового регістру. Темп мовлення повільніший.

Жіноче мовлення у професійному спілкуванні більш чемне, багатослівне, лексично багатше та образніше, емоційніше, відрізняється м'якшою, нерішучою інтонацією. Його граматична будова визначається значною кількістю вставних слів і модальних конструкцій типу «напевно», «здається», дієслів (зокрема умовного способу) та запитань, що підтверджує схильність жінок до вагання, бажання підтвердити власну позицію, численними оціночними висловленнями, прислівниками і прикметниками (значна образність мови), уникненням називання адресата на ім'я. Мелодійність жіночого голосу здатна виражати більше нюансів настрою, почуттів за допомогою інтонації, чому сприяють темп мовлення та короткі паузи [7].

Основою професійного спілкування фахівців із соціальної роботи $є$ взаємодія з клієнтами та колегами, що вимагає оптимізації, зокрема шляхом врахування гендерних особливостей. Чоловіки, будуючи діалог, передусім налаштовані на одержання інформації шляхом прямого апелювання, пропозиції партнеру формулюють коротко, чітко, однозначно, по суті, на відміну від жінок, які для цього ставлять запитання. Саме це допомагає їм швидше дійти згоди, переконати, нав'язати свою волю. Крім того, чоловіки схильні контролювати і скеровувати спілкування до бажаної мети. Вони рідше погоджуються 3 критикою, частіше використовують іронію, звертаються до авторитетів, демонструють статус «експерта» тощо [4].

Жінки здебільшого ініціюють взаємодію, розпочинають та підтримують розмову. Вони дбають про загальну позитивну атмосферу, зорієнтовані на кожну репліку співрозмовника, часто поступаючись своїми позиціями й інтересами, легше приймають поразку і перебивання їх мовлення. Своє незадоволення чи образу демонструють мовчанням. Щоб підтримати зв'язок у процесі спілкування, жінки нерідко «вживають актуалізатори (як-от: «так?», «ви що?», «невже?»), сигнали наявності зворотного зв'язку й уваги до слів співрозмовника («так», «ага», «угу»)» [1, с. 115]. 
Конфронтаційний діалог і дискусія для чоловіків - змога відкрито висловити протест, незгоду, довести власну позицію, перемогти. Ключовим мотивом прийняття рішення для чоловіка-фахівця $\epsilon$ інтереси справи, а жінка дбає, щоб усім було добре, підтримує гарні відносини, інколи просто втілюе свої почуття (помста, повага/неповага тощо).

Як зауважують науковці (О. Безсонова, Ю. Маслова, Т. Осіпова, та ін.), є гендерні відмінності у сприйнятті інформації у процесі взаємодії, серед них: ставлення до зворотного зв'язку (для чоловіків - інформативність, для жінок - взаєморозуміння), готовність вислухати до кінця (жінка дослуховує і дає відповідь чи оцінює, чоловік уважно слухає впродовж перших 20 секунд та висловлює суто власну позицію).

Щоб налагодити продуктивну взаємодію, важливо адекватно використовувати й сприймати невербальні засоби спілкування (жести, міміка, пози, рухи, погляд). Крім того, що невербаліка яскравіша, чіткіша, різкіша в чоловіків, вона відрізняється й змістовно. Специфічно чоловічі жести - почісування потилиці, потирання рук або підборіддя, удар кулаком по столу, обсценні жести відкрито показують роздуми чи рішучість. Їхні пози, що займають багато місця в просторі, виражають домінування, значення, розкутість, а міміка, навпаки, небагата, стримана, не така мінлива, як у жінок. Окремо варто сказати про гендерно марковані особливості погляду. Для чоловіків довгий, прямий, прискіпливий погляд є сигналом про небезпеку, виявом агресії, тиску, приниження, але водночас способом самоствердження, навмисного порушення правил, стереотипно чоловічої поведінки $[4 ; 7]$.

Незнання й неврахування названих гендерних особливостей у професійному спілкуванні і способів їх подолання часто призводить до появи непорозумінь, комунікативних бар'єрів та конфліктів. За визначенням дослідників (С. Дорошенко, Л. Корнєва, А. Чирикова і т.д.), такі комунікативні перешкоди викликані когнітивними, емоційними та поведінковими розходженнями статей. Труднощі у сприйнятті чоловіками жінок пов'язані 3 тим, що останні нібито нездатні адекватно, стримано й раціонально реагувати на проблеми, виправляти власні помилки, пасивні, не вміють обирати пріоритети, психологічно нестабільні, схильні перебивати під час розмови, демонстру- ють емансипованість, застосовують натяки, чим викликають стан дискомфорту та агресії в чоловіків і т.д. Жінки використовують ствердні формулювання (наприклад, «так») для підтримання контакту, водночас чоловіки неправильно трактують це як згоду. На думку жінок, чоловіки своєю чергою швидше змінюють настрій, прагнуть домінувати, самостверджуватися, зосереджені на одній темі, неуважно слухають, не поважають жіночу думку, на стресові ситуації реагують мовчанням і віддалянням (у той час як жінки хочуть виговорися, поділитися емоціями, чекають розради).

Причиною конфлікту для чоловіків, насамперед, $є$ приниження їхньої самооцінки, тоді вони виказують агресивність, підвищують голос, активно жестикулюють, але, вирішивши непорозуміння, швидко забувають про все. Натомість жінки сприймають за особисту образу будь-яке протистояння, напруження у стосунках, навіть ділових, емоційно реагують на нього і довго з'ясовують стосунки, перериваючи спілкування [7].

Наведені гендерні особливості мають стати частиною теоретичної та практичної підготовки майбутніх фахівців із соціальної роботи, увійти до арсеналу професійних інструментів, готовності до фахового спілкування, гендерної і комунікативної культури студентів. Водночас вони сприяють удосконаленню професійно-комунікативної компетентності фахівців-практиків, підвищенню якості спілкування з клієнтами й колегами, подоланню гендерних стереотипів і розширенню професійних ресурсів гендерно маркованими комунікативними стратегіями, новими ціннісними орієнтирами тощо.

Висновки та перспективи дослідження. Феномен гендеру активно увійшов до різних сфер суспільного життя, змінивши парадигму професійної діяльності фахівців із соціальної роботи, що скеровує на врахування гендерних особливостей для оптимізації професійного спілкування. Опанування ними дає змогу сформувати професійно важливі якості, готовність до взаємодії 3 різними категоріями клієнтів у конфліктних, проблемних та ін. ситуаціях.

Перспективи в дослідженні предмета обговорення передбачають вивчення та впровадження ефективних форм і методів формування гендерної культури студентів у процесі їх професійно-комунікативної підготовки.

\section{Література}

1. Бацевич Ф.С. Основи комунікативної лінгвістики : підручник. Київ : Видавничий центр «Академія», 2004. 342 c.

2. Бєссонова О.Л. Оцінний тезаурус англійської мови: когнітивний і гендерний аспекти : автореф. дис. ... д-ра філол. наук : 10.02.04 / Київський нац. ун-т ім. Т. Шевченка. Київ, 2003. 39 с.

3. Глущенко О.О. Вивчення гендерних особливостей мовлення в історичному аспекті. Наукові праці. Філологія. Літературознавство. 2007. Том 70. Випуск 57. С. 108-109. 
4. Дорошенко C.M. Гендерні особливості спілкування. URL: http://www.rusnauka.com/4_SND_2012/ Philologia /8_100640.doc.htm

5. Кайдалова Л.Г., Пляка Л.В. Психологія спілкування : навчальний посібник. Харків : НФаУ, 2011. $132 \mathrm{c}$.

6. Кирилина А.В. Гендер: лингвистические аспекты : монография. Москва : Ин-т социологии РАН, 1999. $155 \mathrm{c}$.

7. Корнєва Л.М. Гендерний аспект комунікації. Філологічні науки : збірник наук. праць. 2013. Вип. 13. C. $106-113$.

8. Крейдлин Г.Е. Просодика, семантика и прагматика невербального коммуникативного поведения: жесты, позы и знаковые телодвижения женщин и мужчин. Гендер: Язык. Культура. Коммуникация : доклады II Международной конференции 22-23 ноября 2001 г. / Моск. гос. лингвистич. ун-т., Лаб. гендерных исслед. Москва, 2002. С. 14-26.

9. Перхайло Н.А. Сучасні комунікативні технології в соціальній роботі : навчально-методичний посібник. Переяслав-Хмельницький : ФОП Домбровська Я.М., 2018. 113 с.

10. Стратегія упровадження гендерної рівності та недискримінації у сфері освіти «Освіта: гендерний вимір - 2020. URL: https://vseosvita.ua/library/strategia-uprovadzenna-gendernoi-rivnosti-tanediskriminacii-u-sferi-osviti-osvita-gendernij-vimir-2020-22689.html.

11. Формування гендерного паритету в контексті сучасних соціально-економічних перетворень : Матеріали міжнар. наук.-практ. конф., 5-7 грудня, 2002 р. м. Київ. Київ : Держ. ін-т проблем сім'ї та молоді; Укр. ін-т соц. досліджень, 2002. 222 с.

12. Tannen D. Du kannst mich einfach nicht verstehen. Warum Maenner und Fraue aneinender vorbeireden. Hamburg, 1991. 164 c.

\section{References}

1. Batsevych F.S. (2004) Osnovy komunikatyvnoyi linhvistyky: pidruchnyk. [Fundamentals of communicative linguistics: a textbook]. K.: Vydavnychyy tsentr «Akademiya», $342 \mathrm{~s}$.

2. Biessonova O.L. (2003) Otsinnyi tezaurus anhliiskoi movy: kohnityvnyi i hendernyi aspekty : avtoref. dys. ... d-ra filol. nauk : 10.02.04 / Kyivskyi nats. un-t im. T. Shevchenka [Evaluative thesaurus of the English language: cognitive and gender aspects]. K., $39 \mathrm{s.}$

3. Hlushchenko O.O. (2007) Vyvchennia hendernykh osoblyvostei movlennia v istorychnomu aspekti [Study of gender features of speech in the historical aspect]. Naukovi pratsi. Filolohiia. Literaturoznavstvo. Tom 70. Vypusk 57. Vydannia ChDU imeni Petra Mohyly, 2007. S. 108-109.

4. Doroshenko S.M. (2012) Genderni osoblyvosti spilkuvannia [Gender aspect of communication]. URL: http://www.rusnauka.com/4_SND_2012/Philologia /8_100640.doc.htm

5. Kaidalova L.H., Pliaka L.V. (2011) Psykholohiia spilküvannia: navchalnyi posibnyk [Pliaka LV Psykholohiia spilkuvannia: navchalnyi posibnyk]. Kh. : NFaU. $132 \mathrm{s.}$

6. Kyrylyna A.V. (1999) Hender: lynhvystycheskye aspektы: monohrafyia [Hender: lynhvystycheskye aspekty: monohrafyia]. M.: Yn-t sotsyolohyy RAN. $155 \mathrm{~s}$.

7. Kornieva L.M. (2013) Hendernyi aspekt komunikatsii [Hendernyi aspekt komunikatsii]. Filolohichni nauky: zb. nauk. prats. Vyp. 13. S. 106-113.

8. Kreidlyn H.E. (2002) Prosodyka, semantyka y prahmatyka neverbalnoho kommunykatyvnoho povedenyia: zhesty, pozy y znakovye telodvyzhenyia zhenshchyn i muzhchyn [Prosody, semantics and pragmatics of nonverbal communicative behavior: gestures, postures and sign movements of women and men]. Hender: Yazyk. Kultura. Kommunykatsyia: doklady II Mezhdunarodnoi konferentsyy 22-23 noiabria 2001 h. / Mosk. hos. lynhvystych. un-t., Lab. hendernykh yssled. M., S. 14-26.

9. Perkhailo N.A. (2018) Suchasni komunikatyvni tekhnolohii v sotsialnii roboti: Navchalno-metodychnyi posibnyk [Modern communication technologies in social work: A textbook]. Pereiaslav-Khmelnytskyi: FOP Dombrovska Ya.M. $113 \mathrm{~s}$.

10. Stratehiia uprovadzhennia hendernoi rivnosti ta nedyskryminatsii u sferi osvity «Osvita: hendernyi vymir - 2020» (2020) [Strategy for the introduction of gender equality and non-discrimination in the field of education]. URL: https://vseosvita.ua/library/strategia-uprovadzenna-gendernoi-rivnosti-ta-nediskriminacii-u-sferi-osviti-osvita-gendernij-vimir-2020-22689.html

11. Formuvannia gendernoho parytetu v konteksti suchasnykh sotsialno-ekonomichnykh peretvoren (2002) [Formation of gender parity in the context of modern socio-economic transformations]. Materialy mizhnar. nauk.-prakt. konf. (5-7 hrudnia, 2002 r. m. Kyiv). K.: Derzh. in-t problem simi ta molodi; Ukr. in-t sots. doslidzhen, 2002. $222 \mathrm{~s}$.

12. Tannen D. Du kannst mich einfach nicht verstehen. Warum Maenner und Fraue aneinender vorbeireden. Hamburg, 1991. $164 \mathrm{~s}$. 